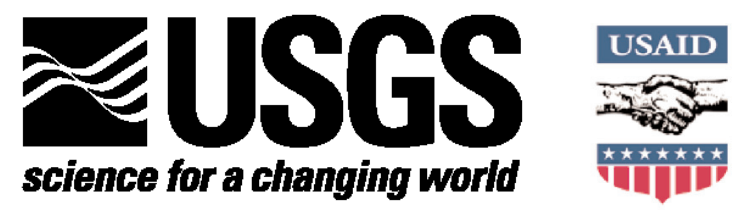

\title{
Digital Inventory of Landslides and Related Deposits in Honduras Triggered by Hurricane Mitch
}

By Edwin L. Harp, Kirk W. Hagaman, Matthew D. Held, and Jonathan P. McKenna

Open-File Report 02-61

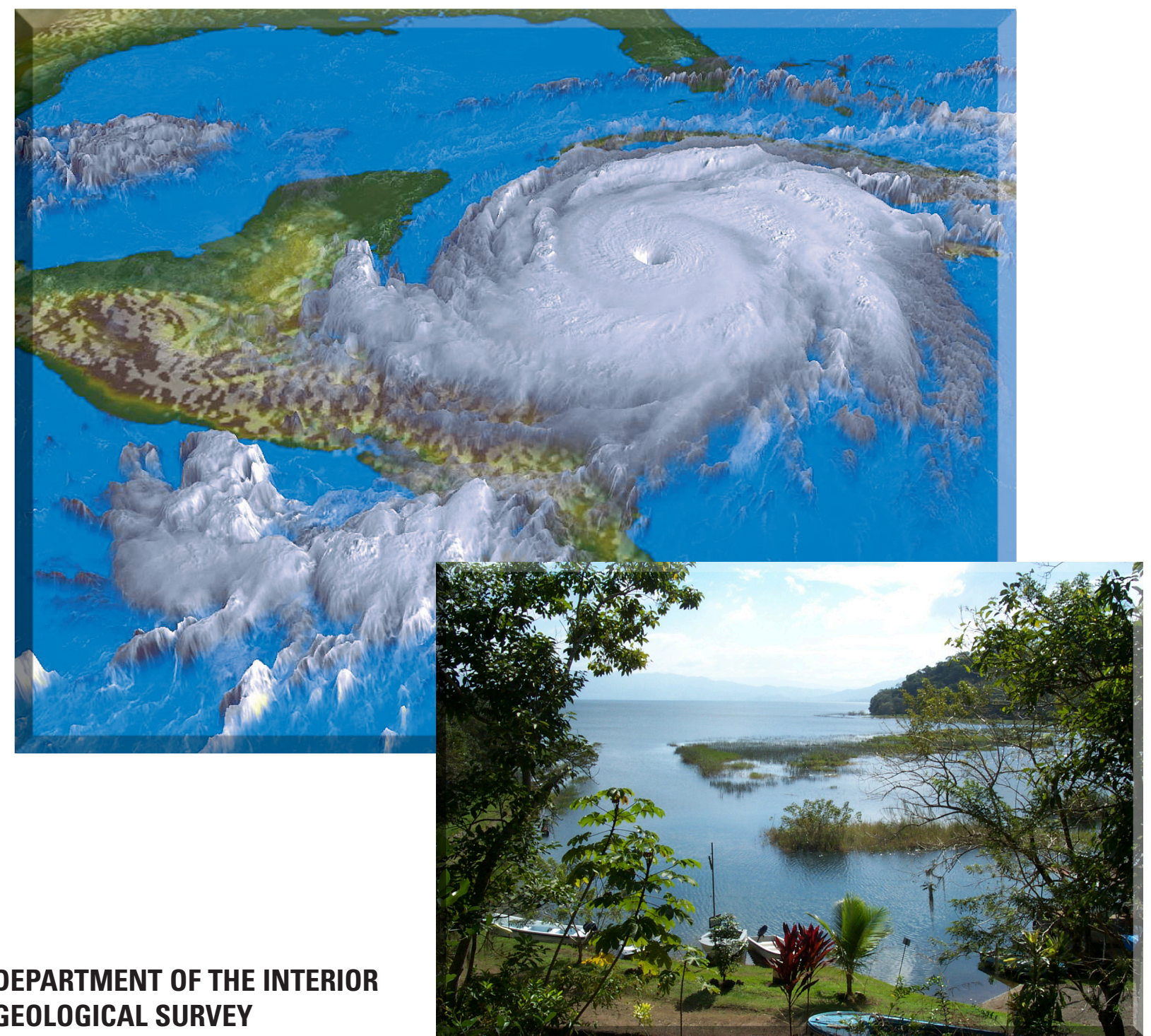




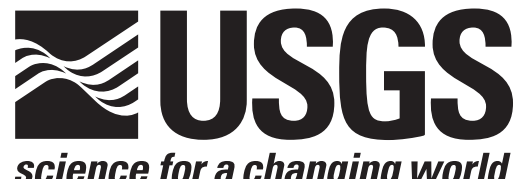

\section{Digital Inventory of Landslides and Related Deposits in Honduras Triggered by Hurricane Mitch}

By ${ }^{1}$ Edwin L. Harp, Kirk W. Hagaman, Matthew D. Held, and Jonathan P. McKenna

Open-File Report 02-61

(English version; Spanish version will also be available)

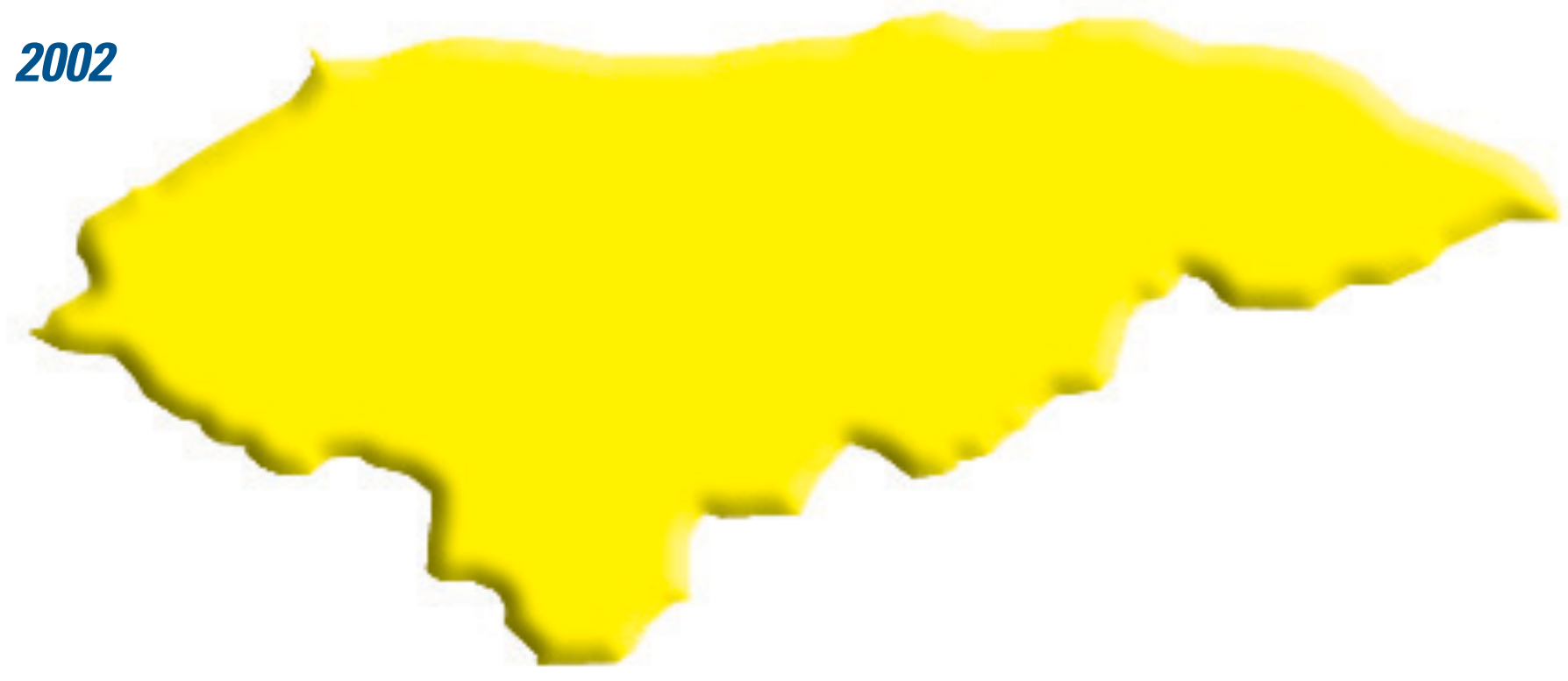

This report is preliminary and has not been reviewed for conformity with U.S. Geological Survey editorial standards or with the North American Stratigraphic Code. Any use of trade, firm, or product names is for descriptive purposes only and does not imply endorsement by the U.S. Government.

\section{U.S. DEPARTMENT OF THE INTERIOR}

U.S. GEOLOGICAL SURVEY

${ }^{1}$ USGS, Denver, Colorado 


\section{Contents}

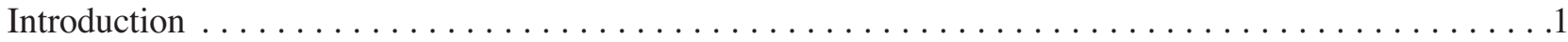

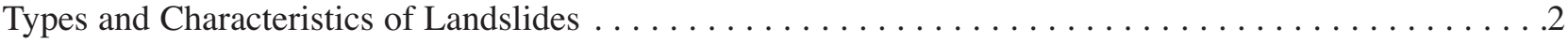

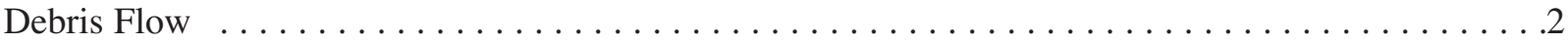

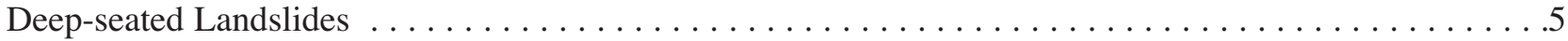

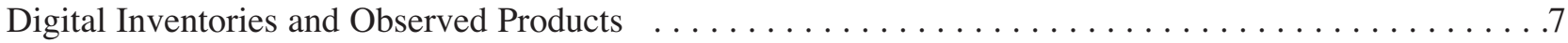

Landslide-Induced Sediment Volumes for Specific Quadrangles $\ldots \ldots \ldots \ldots \ldots \ldots \ldots \ldots \ldots$

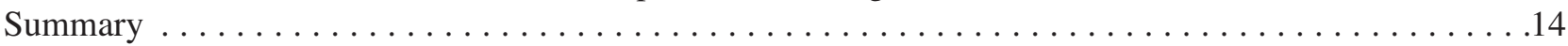

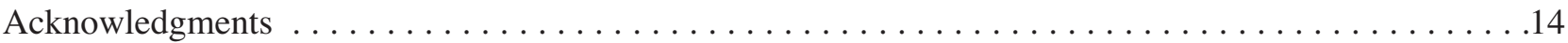

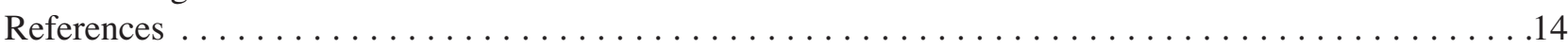

\section{Illustrations}

\section{Figure}

Photographs showing:

1 Slopes near Choluteca showing high concentrations of debris flows

2 Headscarp of Cerro de Uyuca debris flow

3 Distal end of debris flow shown in figure 2

4 Debris flow path through San Juancito

5 Sediment stream produced by debris flows in the Río Viejo

6 Village of Marale and sediment stream produced by a large rotational slump

7 El Berrinche landslide

8 El Reparto slump/debris flow

9 Landslide inventory map of the Choluteca area in southern Honduras

10 Sediment stream produced by debris flows near La Libertád

11 Río Viejo floodplain showing coarse nature of sediment

12 Upstream view of Río Pelo floodplain in El Progreso

13 Stream of sediment being deposited into arm of El Cajón Reservoir

14 Deep-seated slump/debris flow in the headwaters of Río Chilistagua

\section{Plates [in pocket]}

1 Landslide inventory index map of Honduras

2 through 20: Inventory maps of landslides and related deposits

Hurricane Mitch approaching Central America on 26 October 1998,

The hurricane is over the northern half of Nicaragua at

The image is derived from satellite data that has been color-enhanced and

Atmospheres, NASA Goddard Space Flight

Yojoa, Honduras, taken April 2001 by Edwin Harp. 


\title{
Digital Inventory Of Landslides and Related Deposits In Honduras Triggered By Hurricane Mitch
}

\author{
By Edwin L. Harp, Kirk W. Hagaman, Matthew D. Held, and Jonathan P. McKenna
}

ABSTRACT Intense rainfall from Hurricane Mitch from October 27-31, 1998, exceeded $900 \mathrm{~mm}$ in places in Honduras and triggered in excess of 500,000 landslides throughout the country. Landslides damaged an estimated 70\% of the road network in Honduras based on estimates by the U.S Army Corps of Engineers. Numbers of fatalities due to landslides are not accurately known due to the fact that numerous small villages throughout Honduras lost residents to landslides without an official count being recorded. A conservative estimate would place the number at near 1,000.

Debris flows accounted for over 95\% of the landslides and ranged in thickness from 1 to $15 \mathrm{~m}$. Flow path lengths of these failures ranged from several meters to $7.5 \mathrm{~km}$. The highest concentrations of debris flows occurred in the mountains near the town of Choluteca where over $900 \mathrm{~mm}$ of rain fell in three days.

Although landslides other than debris flows were few, several deep-seated landslides in the city of Tegucigalpa severely impacted people and property. The "El Berrinche" rotational slumplearth flow of approximately six million cubic meters volume destroyed the entire neighborhood of Colonia Soto near the center of the city. The landslide also dammed the Rio Choluteca and created a lagoon behind the landslide dam, which immediately posed a health problem for the city, because raw, untreated sewage was emptying into the Rio Choluteca.

Several areas of highly concentrated landslides have been responsible for much of the flooding problem as well. Huge sediment influxes from landslide source areas near La Ceiba, La Libertád, Marale, and in several arms of El Cajón Reservoir have reduced stream capacities to practically nothing and have exacerbated flooding conditions in even the moderate rainfall seasons since Hurricane Mitch.

The ongoing hazard to communities from landslides triggered during Hurricane Mitch are being analyzed using aerial photography taken by the U.S. Air Force and by supplemental photography taken by local contractors. Through the use of digital elevation models derived from 1:50,000-scale topographic maps and geologic maps, landslide susceptibility maps will be derived to aid land-use planning and relocation efforts.

\section{Introduction}

$\mathrm{T}$ The arrival of Hurricane Mitch in Honduras in the latter part of the normal hurricane season produced effects that were unprecedented in their widespread nature throughout Central America. After winds from the storm had blown down over $70 \%$ of the conifer forest on the Bay Island of Guanaja, the hurricane turned inland and lingered over the mainland of Honduras for days where the deluge of rainfall proved to be the devastating agent as it produced flooding and land- slides that resulted in over 9,000 fatalities and 3 million people displaced. Although the eye of Hurricane Mitch passed through the northern part of Honduras, the greatest rainfall totals and intensities were experienced in the southern part of the country near Choluteca. For the three days October 29, 30, and 31, 1998, rainfall at Choluteca exceeded $900 \mathrm{~mm}$. Not surprisingly, it was in this area that the highest landslide concentrations occurred (figure 1). 
Figure 1. Slopes near Choluteca showing high concentrations of debris flows.

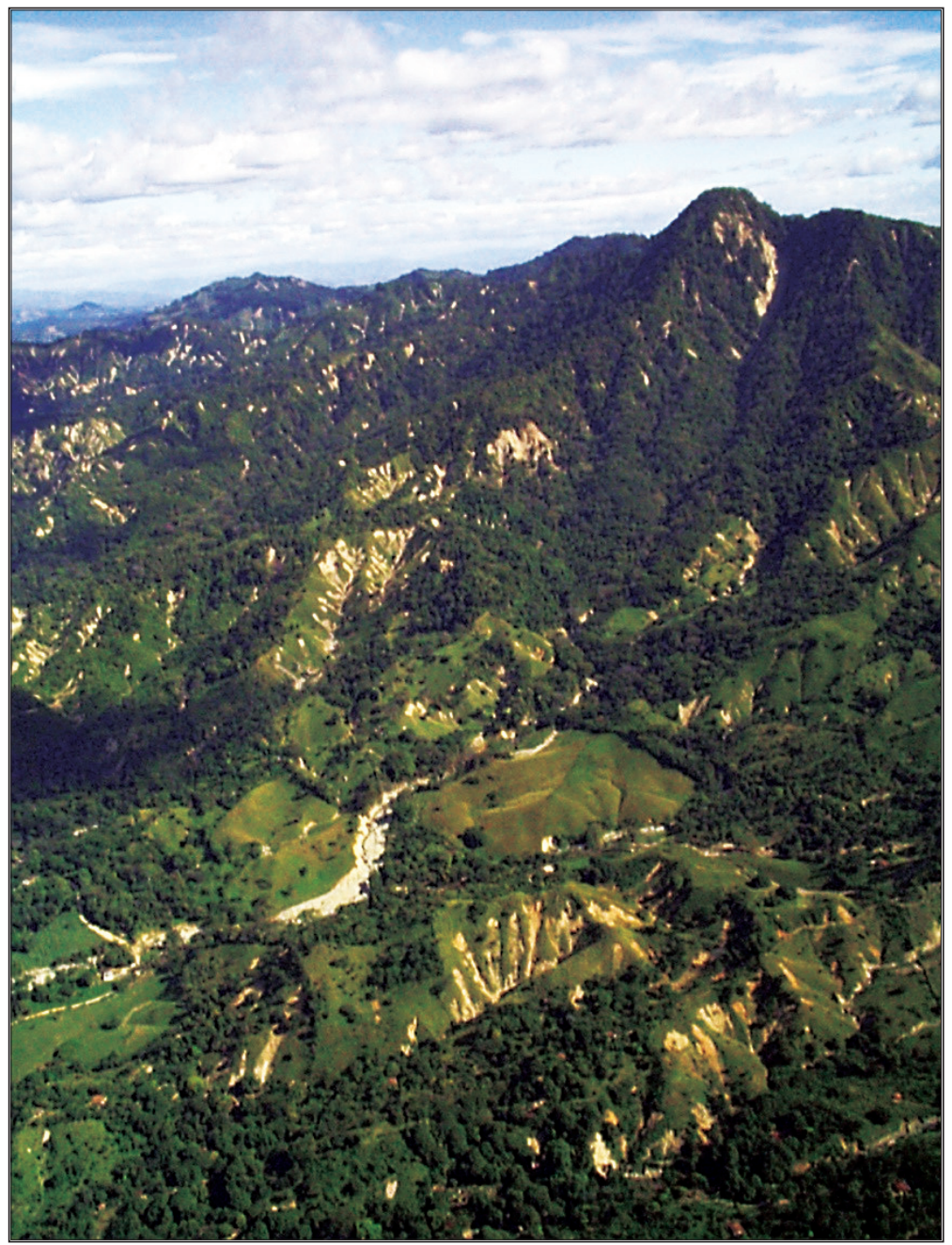

short lengths of travel, generally $100 \mathrm{~m}$ or less. There were exceptions in which debris flows traveled several hundred meters and in a few cases nearly $1 \mathrm{~km}$, but these were limited to less than $10 \%$ of the total population of landslides. The dry tropical desert climate of the southern part of the country has produced thin soils that result in the shallow depths of the debris flows there.

In other parts of Honduras where a less desert-like climate prevails, soils and weathered bedrock are found

\section{Types and Characteristics of Landslides}

\section{Debris Flows}

$\mathrm{O}_{\mathrm{s}}^{\mathrm{f}}$ the hundreds of thousands of landslides that were triggered in Honduras by Hurricane Mitch over 95\% were debris flows, highly remolded slurries of soil, rock, and water that often move at velocities of up to $50 \mathrm{~km} / \mathrm{hr}$ and travel several kilometers. Debris flows ranged in thickness from less than 1 to $15 \mathrm{~m}$. Debris flows in the southern part of Honduras in the area around Choluteca tended to be rather shallow with depths of $2 \mathrm{~m}$ or less and to have to greater depths, and debris flows attained commensurately greater thicknesses. In many cases, debris flows have cut into weathered volcanic rocks to depths of $15 \mathrm{~m}$, and the debris flows were more confined to stream channels and gullies, many of which have long run out distances of several kilometers or greater. Southeast of Zamorano in the San Buenaventura Valley, numerous debris flows exceeded $4 \mathrm{~km}$ in length. The longest debris flow in Honduras triggered by Hurricane Mitch originated in the cloud forest high on the slopes of Cerro de Uyuca (figure 2) and traveled for $7.5 \mathrm{~km}$. At the distal end of this flow, 68 dwellings were destroyed in the village of El Jicarito (figure 3). 
Figure 2. Headscarp of Cerro de Uyuca debris flow.
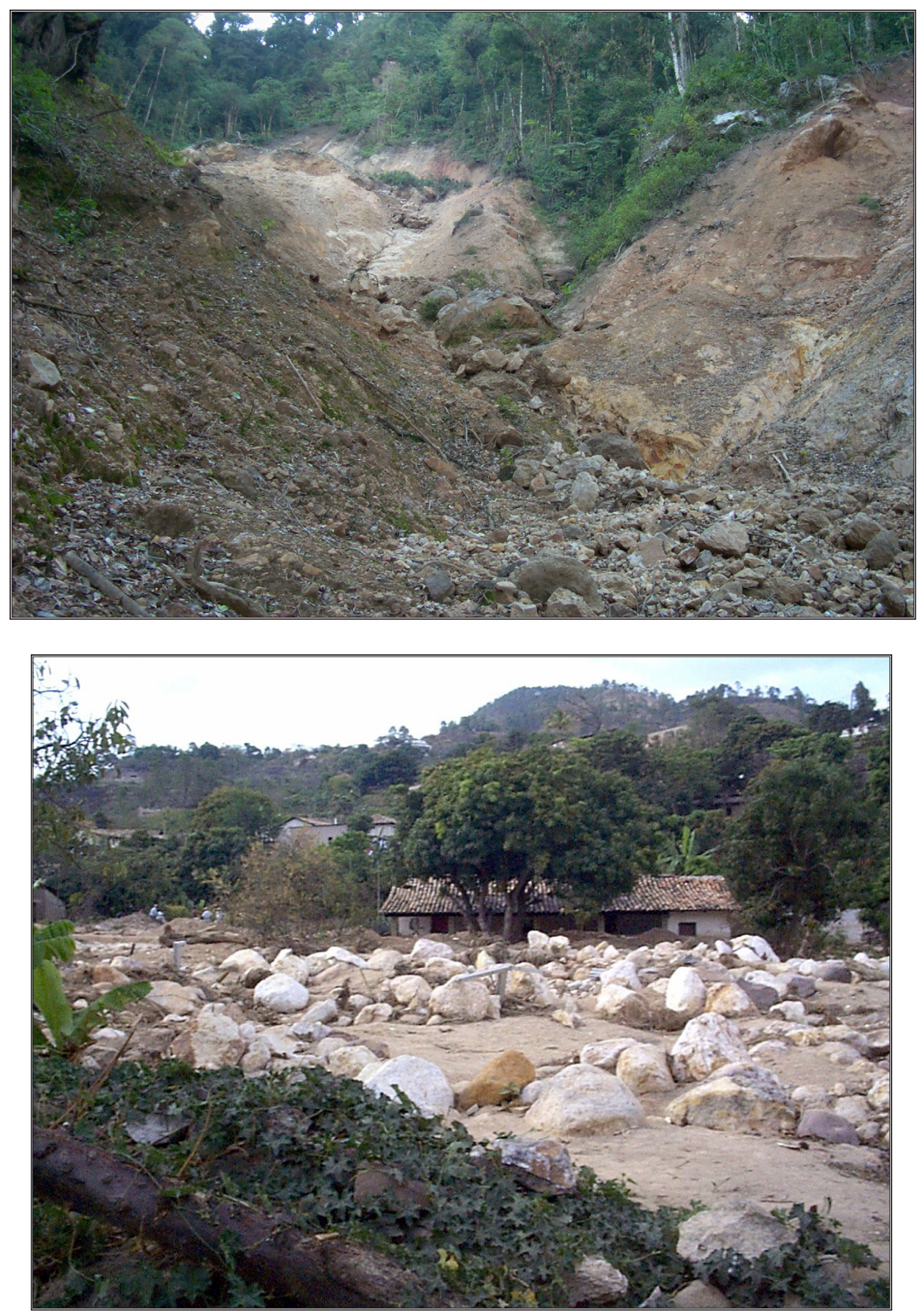

Similarly, in the historic mining town of San Juancito, approximately $25 \mathrm{~km}$ northeast of Tegucigalpa, several debris flows with long run out paths occurred in the cloud forest of La Tigra National Park. One of these debris flows originated in the mine tailings of one of the shafts of the El Rosario Mine. The initial slump destabilized the slope within a gully for $150 \mathrm{~m}$ upslope from the original source area, which also failed and mobilized a debris flow which scoured the entire length of the stream gully down to and through the town (figure 4).

Numerous houses and other structures including a school were destroyed as the debris flow passed through the town center and continued downstream for another kilometer. 


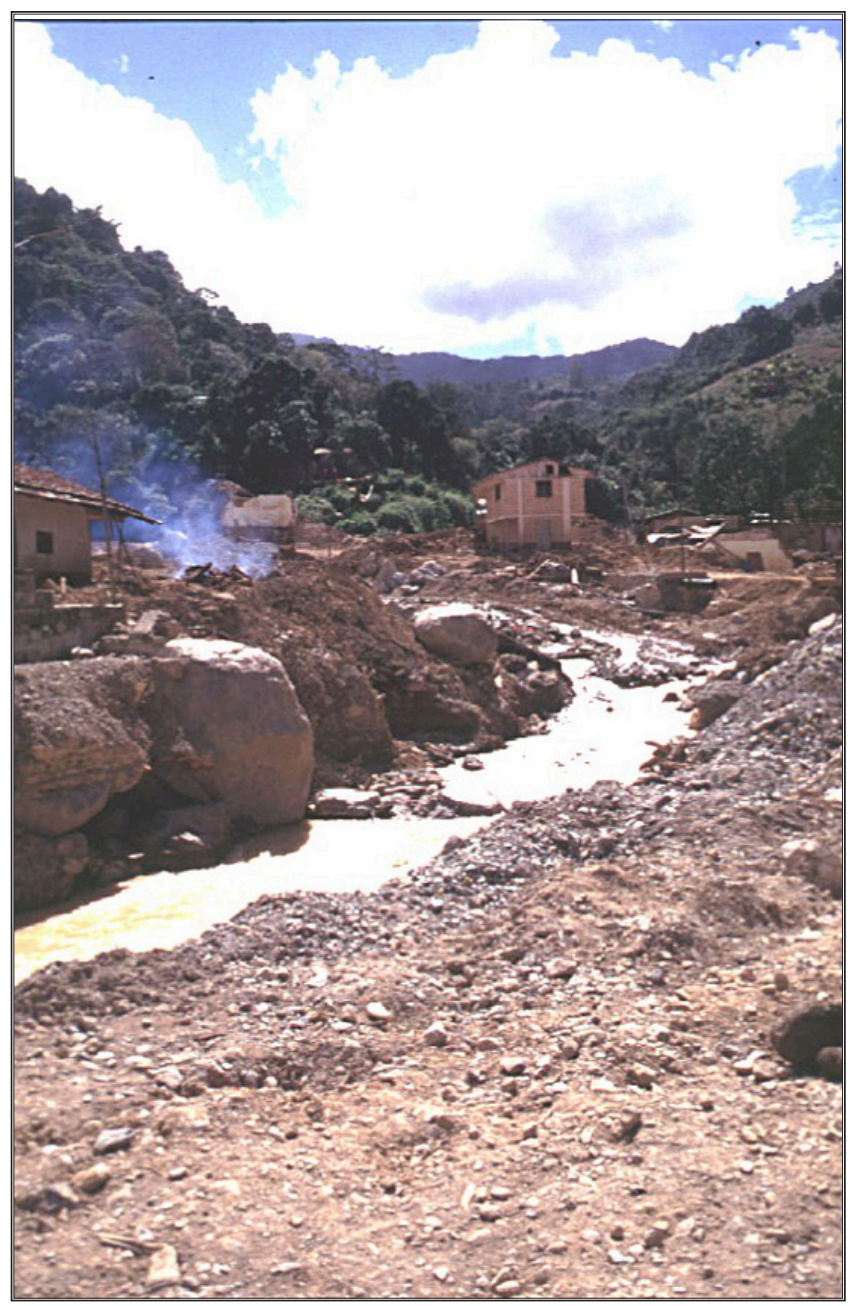

Figure 4. Debris flow path through San Juancito.

The concentration of landslides throughout the country was variable. Although some landslides occurred in almost every part of the country from Hurricane Mitch rainfall, significant damage and ongoing hazards from landslides generally were limited mainly to areas where there were pockets of high concentrations. Some of these occurred in extremely remote areas where the impact to people and property was minimal. However, most of the areas where landslide incidence was high coincided with areas with significant populations.

The cities of La Ceiba and El Progreso, as well as the villages of Marale and La Libertád suffered more from the related problem of sedimenta- tion caused by the landslides than from the landslides themselves. Large sediment streams choking the rivers that flow near these population centers have caused avulsion of the rivers and diversion of flood waters into residential areas. In La Ceiba, El Progreso, and La Libertád, extremely large concentrations of debris flows and debris slides in the watersheds upstream from these centers have inundated the streams with sediment that will cause flooding and stream diversion problems for years to come (figure 5). Similar problems in the village of Marale in central Honduras were caused by one large rotational slump that provided debris to the stream that flows next to the village (figure 6). 
Figure 5. Airphoto

of sediment

stream produced

by debris flows in

the Río Viejo, a

tributary of the Río

Cangrejál that

flows through La

Ceiba.

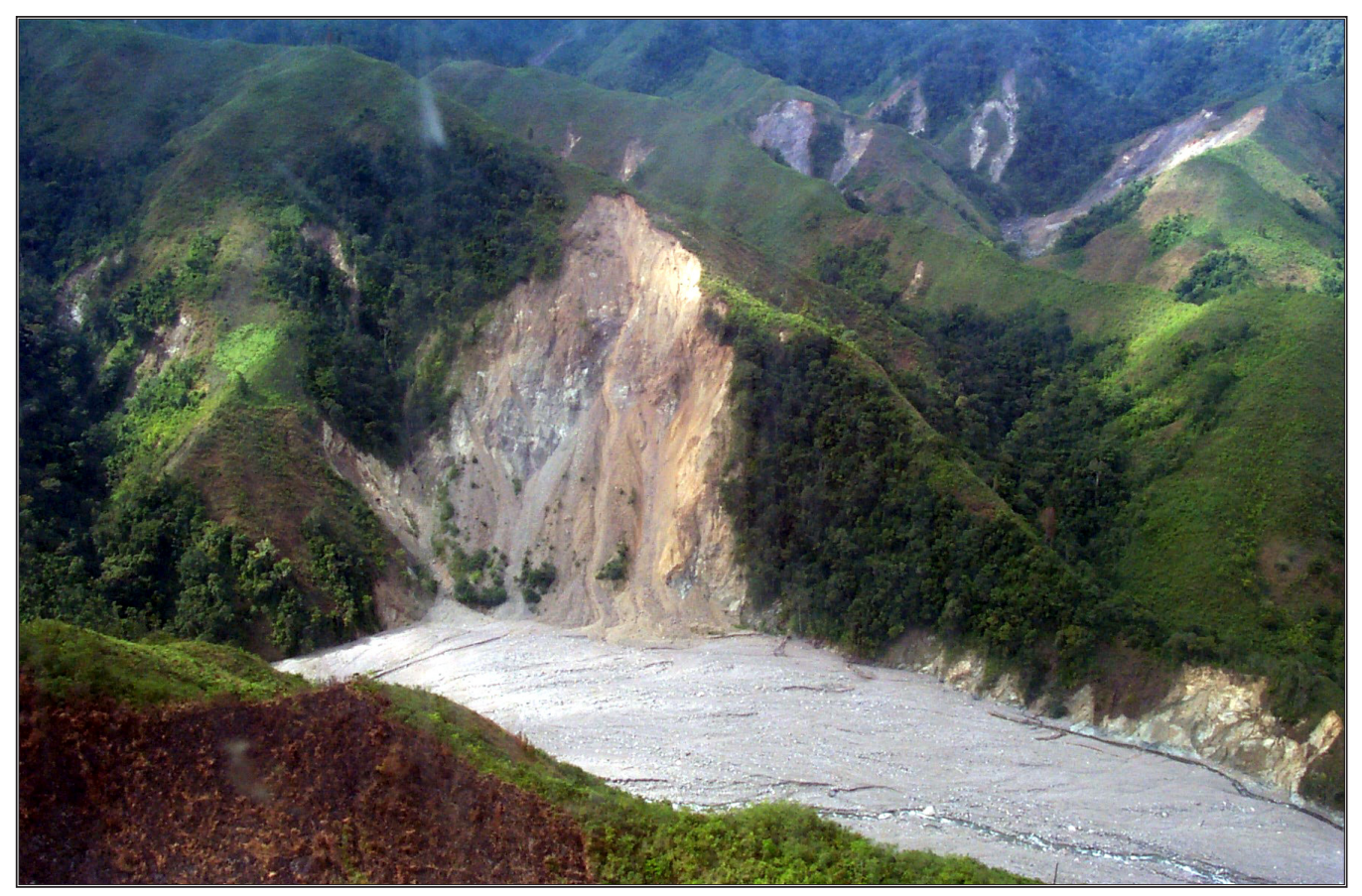

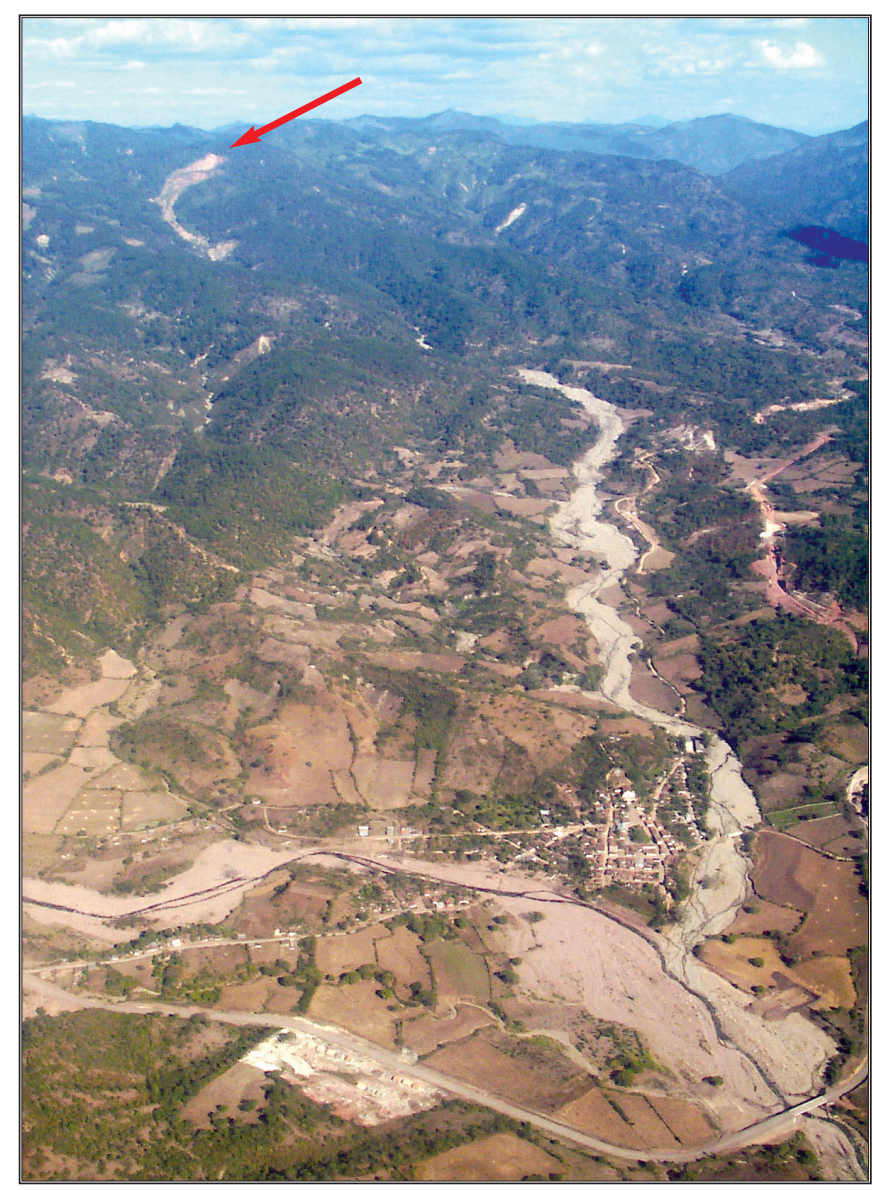

Figure 6. Aerial view of the village of Marale in the right foreground and the sediment stream produced by a large rotational slump in the distance (arrow).

\section{Deep-Seated Landslides (slumps, earth flows, etc.)}

lthough small in number, deep-seated Alandslides had an extremely large impact on people and property due to the fact that many of them occurred in heavily populated areas. The largest of the landslides in this category triggered by Hurricane Mitch occurred in Tegucigalpa, destroying a portion of the central part of the city known as Colonia Soto and damming the Río Choluteca, creating a sewage-filled lagoon upstream from the landslide dam (figure 7). This complex slump/earth flow had a volume of approximately 6 million cubic meters. Because of previous slow movement of the landslide, city residents living on the landslide mass were evacuated prior to its rapid movement that culminated in the damming of the river. The river was dammed at approximately 12:30 a.m. on October 31, about 1 hour after the peak flood flow of the Río Choluteca. 
Figure 7. Aerial view of the EI

Berrinche land-

slide, a complex

rotational

slump/earth flow

that dammed the

Río Choluteca in

Tegucigalpa. The arrow indicates

the direction of

movement of the

earth-flow tongue.

" $T$ " denotes the toe

of the landslide

that dammed the

river, and "L" indi-

cates the lagoon

dammed by the toe

of the landslide.

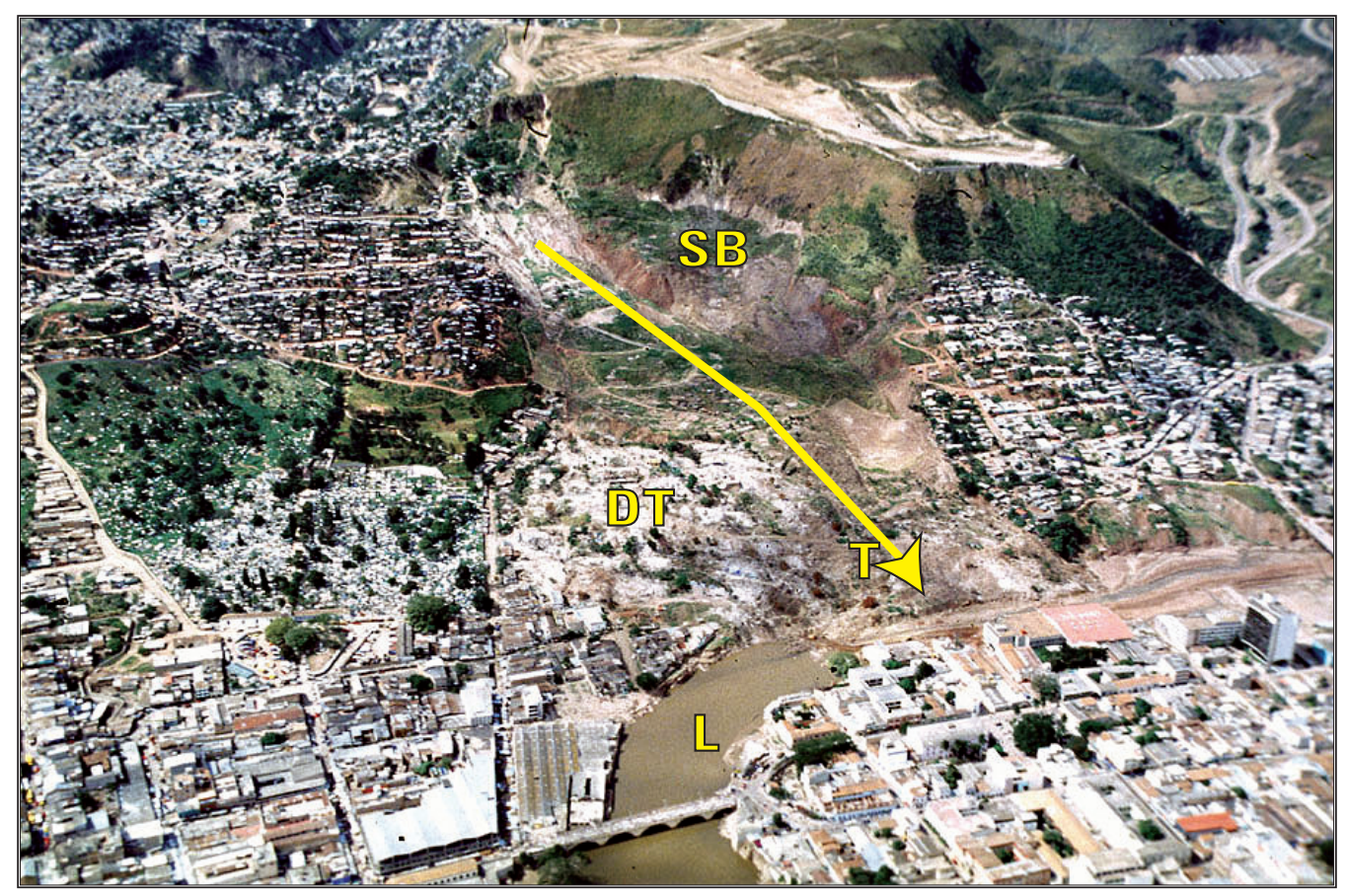

Another deep-seated landslide, a rotational slump/debris flow with a volume of $400,000 \mathrm{~m}^{3}$ destroyed numerous houses in the Colonia El Reparto section of Tegucigalpa (figure 8). This landslide occurred on October 31 during the midmorning hours over a timespan of several hours. The final movement of the slump resulted in the formation of a debris flow, which mobilized from the oversteepened toe of the landslide and demolished the houses.

Figure 8. Aerial view of the EI Reparto slump/debris flow.

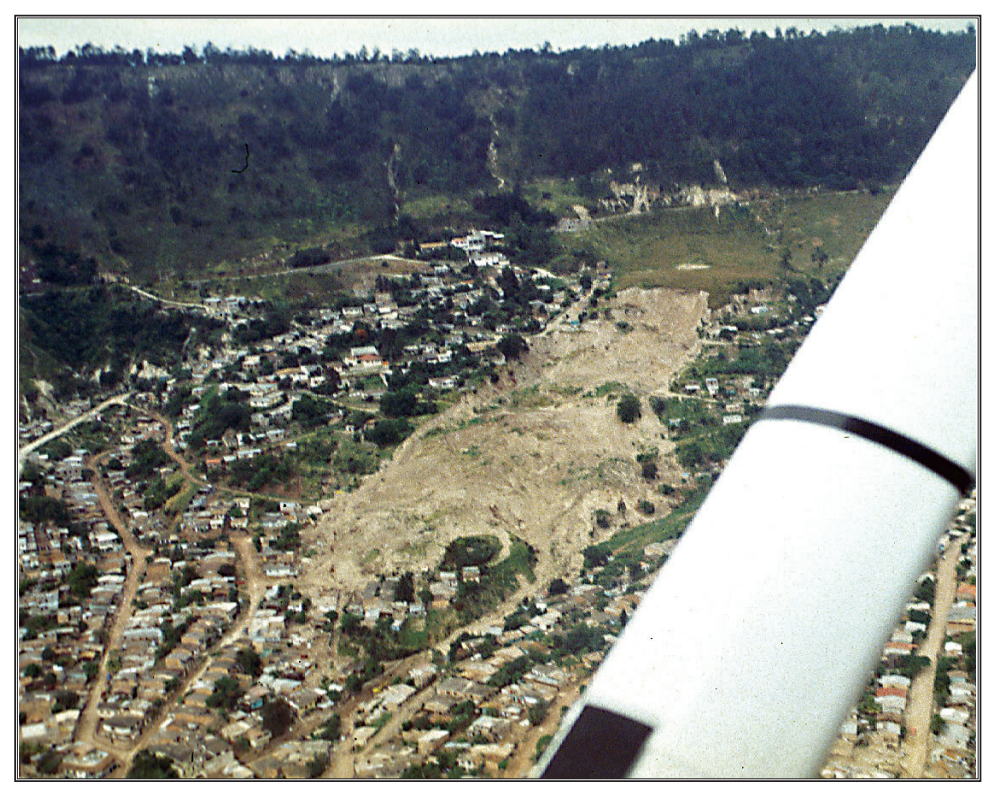




\section{Digital Inventories and Derived Products}

$\mathrm{I}^{\mathrm{n}}$ $n$ an effort to document the landslides triggered by Hurricane Mitch, the landslide inventory maps featured by this report are produced at scales of 1:50,000 for those municipalities with significant landslide hazards (Plate 1, figure 9). The inventory maps are prepared using the aerial photography taken in the months following Hurricane Mitch by the U.S. Air Force under Project Open Skies and additional aerial photography taken by a local contractor. Both sets of aerial photography were taken as black-and-white images at a scale of $1: 40,000$. The aerial photographs were viewed in stereo projection to locate landslides and plot them on 1:50,000-scale topographic maps.

Their outlines were sketched by hand onto the topographic maps. Accuracies of landslide locations obtained by this process are estimated to be better than $100 \mathrm{~m}$ in areas of low slopes and heavy vegetation to better than $50 \mathrm{~m}$ in areas of high topographic relief and distinct topography with little vegetation. In some cases, field examination of mapping established that some locations were accurate to within $20 \mathrm{~m}$. Plate 1 shows the areas where landslides were mapped in relation to the country boundary, major cities, and the 1:50,000-scale topographic quadrangles within the country.

In addition to inventory maps, a map showing relative landslide susceptibility (Harp and others, 2002) for the city of Tegucigalpa is being prepared using its landslide inventory, geologic map, and triangulated irregular network model (TIN) derived from the 1:10,000-scale topographic map of the city. The landslide inventory, the TIN, and estimated representative shear strengths of the geologic materials depicted on the geologic map are combined in a GIS-based infinite slope analysis to calculate relative landslide susceptibility.

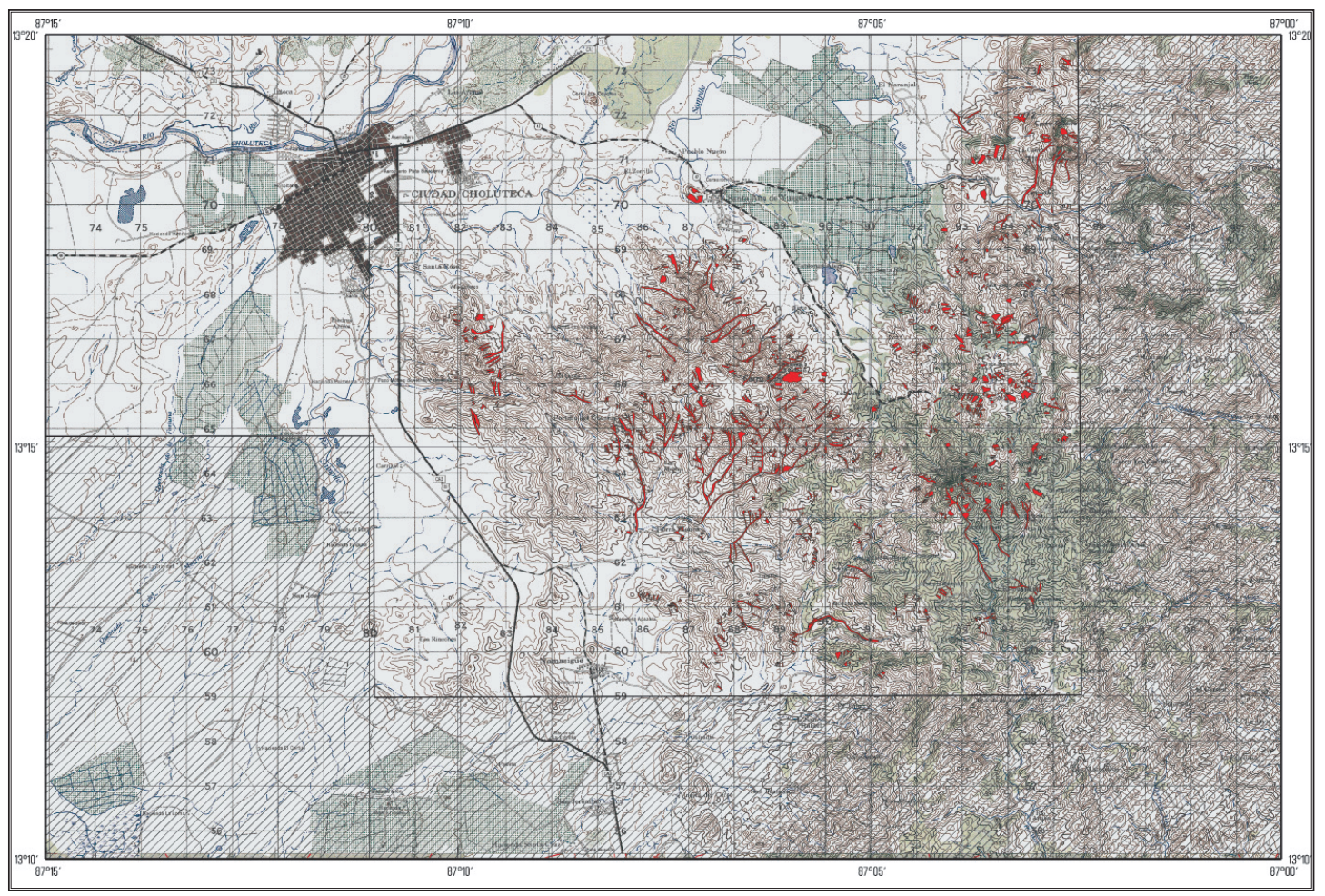

Figure 9. Landslide inventory map of the Choluteca area in southern Honduras. 
A collateral hazard that has been described above is due to the sediment produced by landslides that is being processed by the stream network. In addition to the populations at risk from this phenomenon, the largest reservoir in the country, El Cajón Reservoir, is receiving large volumes of sediment from landslides in two of the reservoir's arms. In its northeast extension just south of Montaña de Pijól, a 3-km-long stream of boulders and other sediment is making its way into the reservoir, building a large delta. A similar situation exists downstream from La Libertád (figure 10). Here the sediment from debris flows in the watersheds above the village is being transported along the Río Quirima and into the southernmost arm of the reservoir.
The inventory and susceptibility maps as well as sediment-volume estimates are digital products prepared on a Geographic Information Systems (GIS) platform that can be used by local agencies to plan relocation efforts or mitigation actions. Hardware, software, and the training necessary to reproduce these products and to conduct similar analyses for future landslide problems is being given to personnel in local and national agencies in Honduras so that the capability to document and analyze landslide hazards will reside within the country after the reconstruction and mitigation efforts are completed.

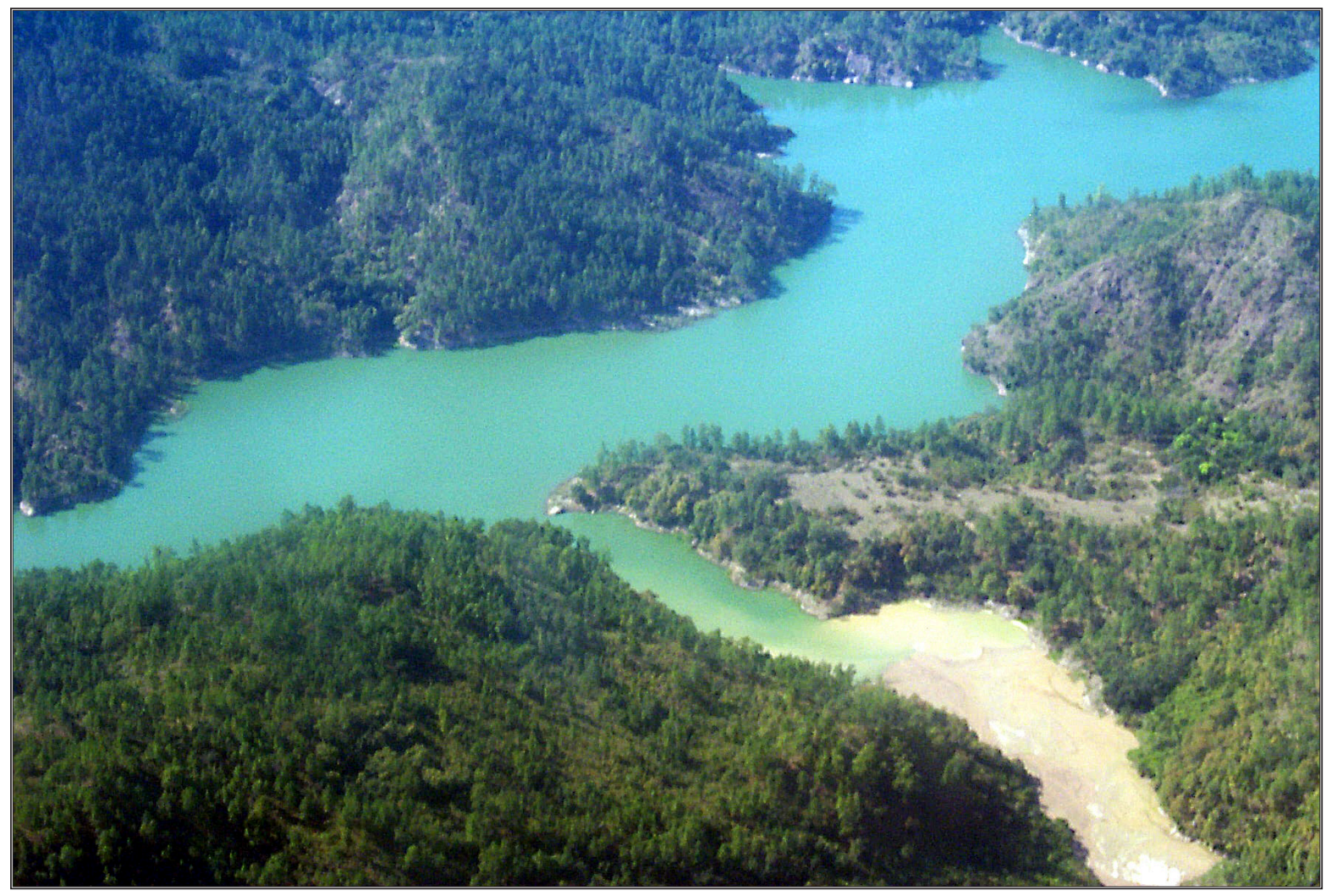

Figure 10. Aerial view of sediment stream produced by debris flows near La Libertád. Sediment is shown here flowing down the Río Quirima and into El Cajón Reservoir. Light area in lower right arm of reservoir is almost entirely sediment. 


\section{Landslide-Induced Sediment Volumes for Specific Quadrangles}

$\mathrm{T}$ his section of the report discusses the sediment influx originating from landslide sources in some of the stream systems in Honduras and tabulates GISbased estimates of sediment volumes that have been produced by landslides in drainages that have been affected by high concentrations of landslides. Many of these areas now suffer from stream avulsion due to increased sediment loads within active river channels. In many of these cases, the river channels are much more prone to flooding and active channel diversion because of the reduced capacities of the river channels. Still other areas of large sediment influx from landslide sources include reservoirs where storage capacity is being diminished as streams entering the reservoirs discharge the sediment load. In addition to landslides, the sediment streams within active channels that are largely derived from landslide debris are mapped as separate polygons on the 1:50,000-scale map sheets. Specific areas where the sediment volume is estimated are:

Río Viejo tributary to the Río Cangrejál (Pico Bonito Quadrangle),

Río Bonito and Río Perla drainages south of La Ceiba (La Ceiba Quadrangle), Streams draining western slopes of Mico Quemada Range east of El Progreso

(El Progreso and Villanueva

Quadrangles),

Streams draining the south flank of Montaña de Pijól near El Cajón

Reservoir (Las Flores Quadrangle),

Río Quirima draining area near La

Libertád (La Libertád Quadrangle), and lower Río Choluteca basin

(Choluteca, Orocuina, Soledad, and

San Lorenzo Quadrangles).

Our method of estimating the sediment yield from landslide sources is a fairly crude one designed to give an order of magnitude estimate of the total volume discharge. Each landslide polygon mapped onto the topographic map has a source area and a depositional area. The relative proportion of source area to depositional area varies from landslide to landslide. If the source area is exceptionally steep, it may cover a small area compared to the area of deposition, especially if the deposit is located on fairly flat terrain. Since almost all source areas originate on slopes steeper than the areas of deposition, ratios of source area to depositional area tend to range from 0.2 to 0.5 , with the trend being toward the lower values. Despite the variability in the source to deposition ratio, we assume, for our order-of-magnitude calculations that source and depositional areas are equal. We compute the area of each polygon, divide it by two, and then multiply this by the average debris-flow source depth in the area of concern. The average debris-flow depth we employ for the southern part of Honduras in the area of Choluteca is $0.5 \mathrm{~m}$ while the average depth assumed for the central and northern parts of the country is $2.5 \mathrm{~m}$. The lower average depth used in southern Honduras reflects the shallow soils produced by the tropical desert climate present there. The deeper averages used in the central and northern parts of Honduras are due to the higher annual rainfalls received in these tropical valleys and cloud forests of the upland areas. Here, the greater rainfall produces deeply weathered volcanic soils of up to $15 \mathrm{~m}$ judging by some of the debris-flow scars observed.

The following list of quadrangles includes the estimated sediment volume produced by landslides in those quadrangles and an estimate of the degree to which this sediment is likely to be mobilized into the stream network. Other comments pertaining to susceptibility of geo- 
logic materials to landslides and ongoing landslide hazards are also included for those quadrangles where they apply.

\section{Pico Bonito Quadrangle (2862 IV, Plate 3)}

Sediment volume: $16,730,000 \mathrm{~m}^{3}$.

The sediment volume produced by landslides in this quadrangle is by far the largest of all the quadrangles in Honduras where landslides introduce significant volumes of debris into the drainage network. Within this quadrangle, most of the sediment load in the stream network that ultimately flows into the Río Cangrejál originates in the headwaters of the Río Viejo. This is the only tributary to the Río Cangrejál that has a significant landslide concentration. The thousands of landslides that were trig- gered by Hurricane Mitch in this drainage are fully linked to the stream system and have completely filled the flood plain of the Río Viejo (fig. 5). The average diameter of the sediment produced is extremely coarse with almost no silt or finer size fraction present (figure 11). At present, three years after the hurricane, debris flows in the Río Viejo drainage still have significant volumes of material that will enter the stream system.

Other source areas of debris flows within this quadrangle are within the headwaters of the Río Bonito and the Río Perla. Debris flows in these areas contribute sediment that has been transported downstream into the lower reaches of these drainages in the La Ceiba

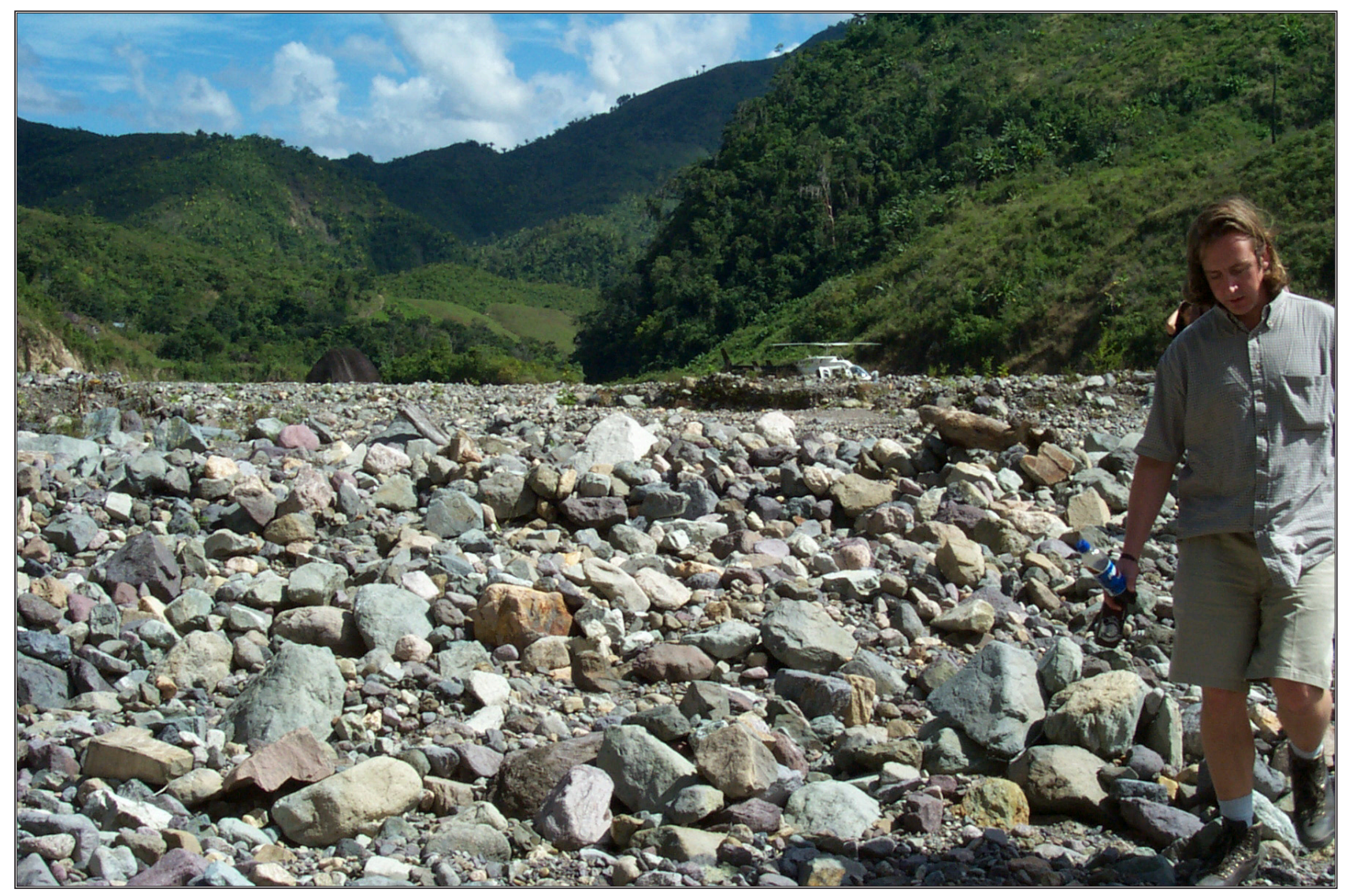

Figure 11. View of Río Viejo flood plain showing coarse nature of sediment. 


\section{La Ceiba Quadrangle (2863 III, Plate 2)}

Sediment volume: $502,000 \mathrm{~m}^{3}$. The main river drainages affected by debrisflow sediment are the Río Bonito and the Río Perla. Most of the sediment volume produced by debris flows in these drainages is within the Pico Bonito Quadrangle to the south. As with the Río Viejo drainage, these drainages will continue to have sediment moving from the debris-flow source areas to the main river channels for several more years, which will increase the tendency of these rivers to flood.
El Progreso Quadrangle (2662 III, Plate 4)

Sediment volume: $312,000 \mathrm{~m}^{3}$. The volume of sediment produced by landslides in this quadrangle and, in particular, the Río Pelo watershed is far too small to account for the inundation of alluvial sediment that affected the river channel where it passes through the city of El Progreso (figure 12). With so few landslides evident from post-Mitch aerial photography of the Río Pelo watershed, the conclusion is that the sediment was derived mainly from erosion-induced channel scour.

Figure 12. Upstream view of Río Pelo flood plain in El Progreso in January 1999 showing inundation of the river's channel with sediment derived primarily from erosioninduced channel scour in the upstream watershed during Hurricane Mitch.

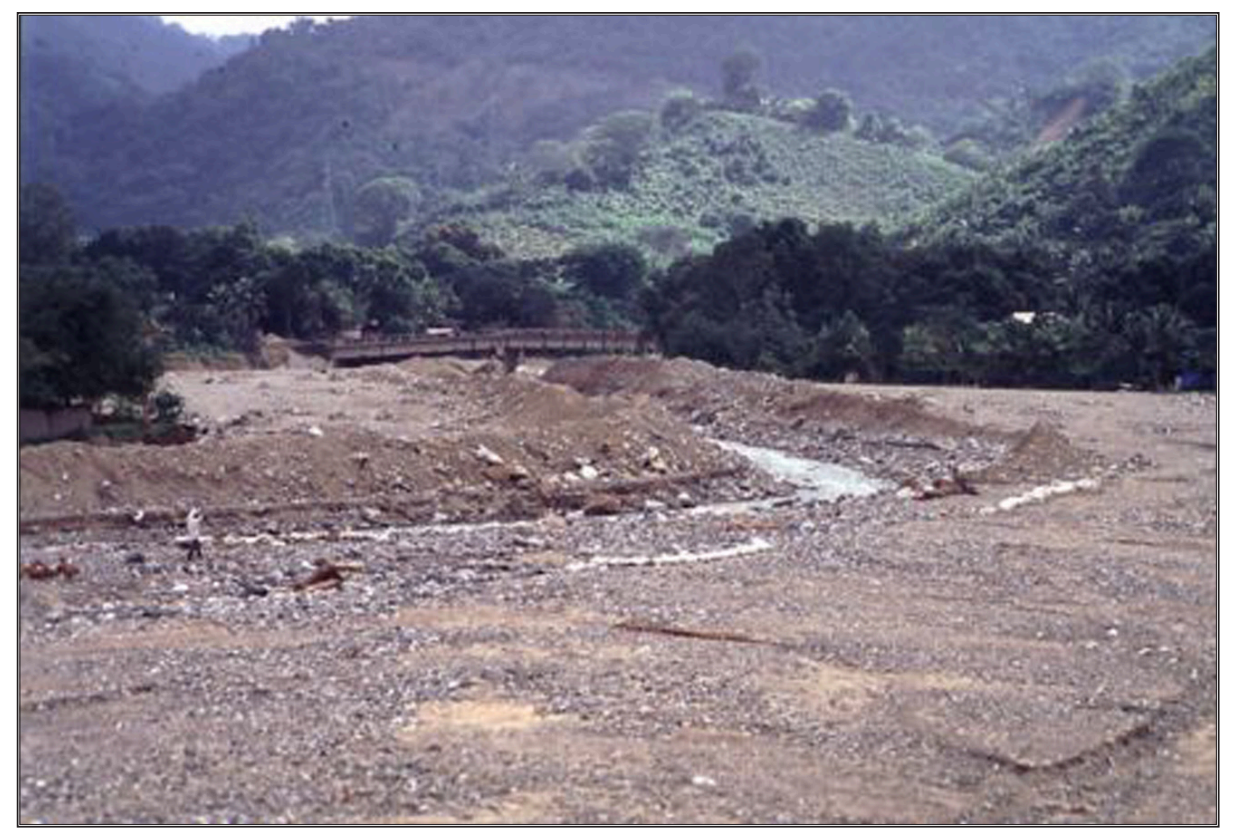

\section{Villanueva Quadrangle (2661 IV, Plate 5)}

Sediment volume: $1,825,000 \mathrm{~m}^{3}$.

Landslides in this quadrangle, particularly in the Quebrada Guacamaya and Quebrada La Mina drainages account for most of the sediment supplied by landslides to the stream network in the Mico Quemado mountain range. Debris flows triggered in the southern part of this range are well linked with the stream drainages so that debris-flow sediment has access to the main channels and will contribute to the stream sediment load for several years to come.
Las Flores Quadrangle (2661 II, Plate 6)

Sediment volume: $4,520,000 \mathrm{~m}^{3}$.

Landslides in the upper drainages of streams that flow into El Cajón Reservoir have created two 5-km-long streams of sediment that merge and have deposited large volumes of sediment into the reservoir (Plate 6, figure 13). The headwaters of the Río Chilistagua and Quebrada de Yorito have hundreds of debris flows and several large deep-seated slump/debris flows (figure 14) that are well-linked to the stream network. 


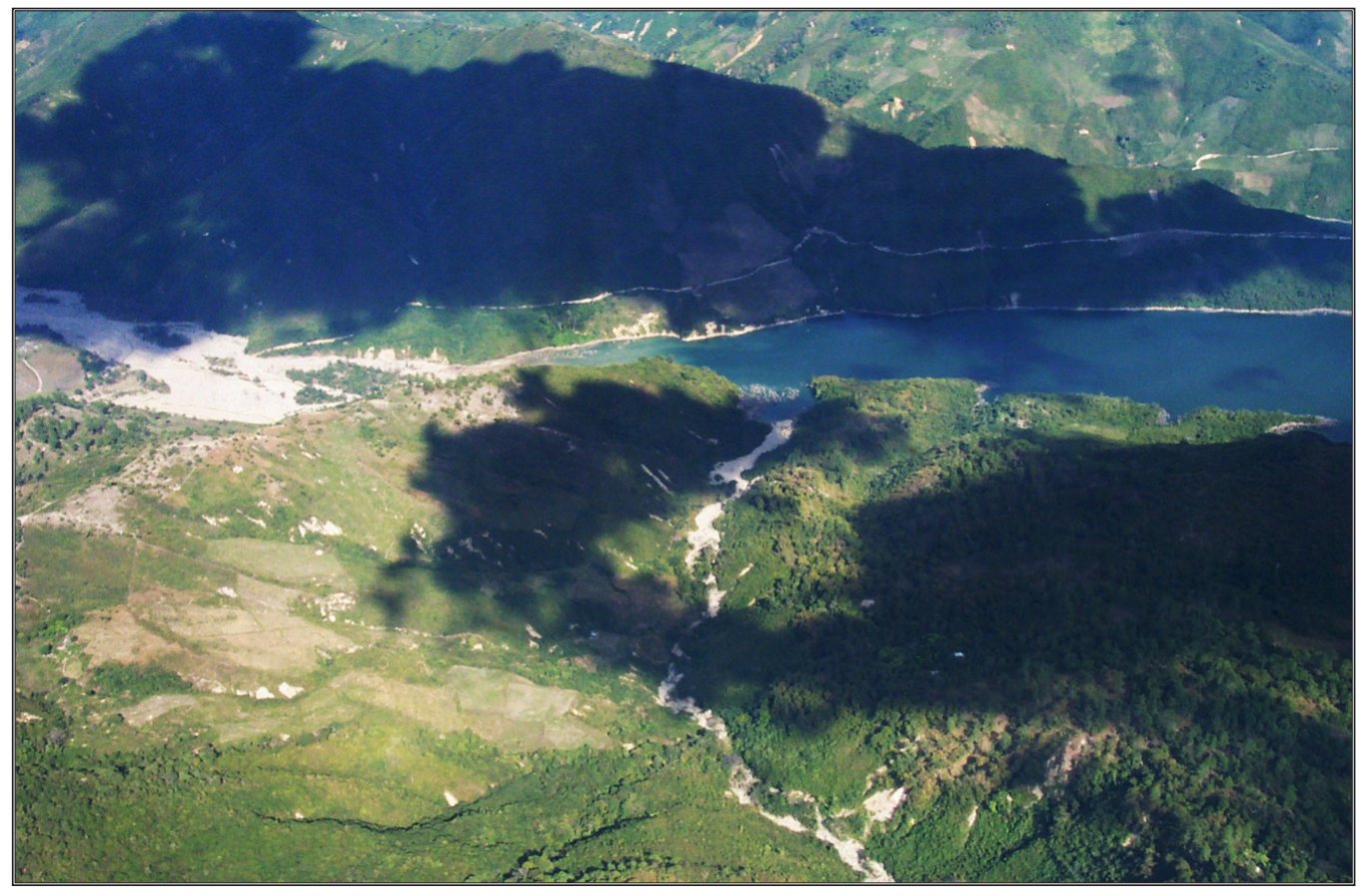

Figure 13. Stream of sediment mainly from landslides being deposited into arm of El Cajón Reservoir.

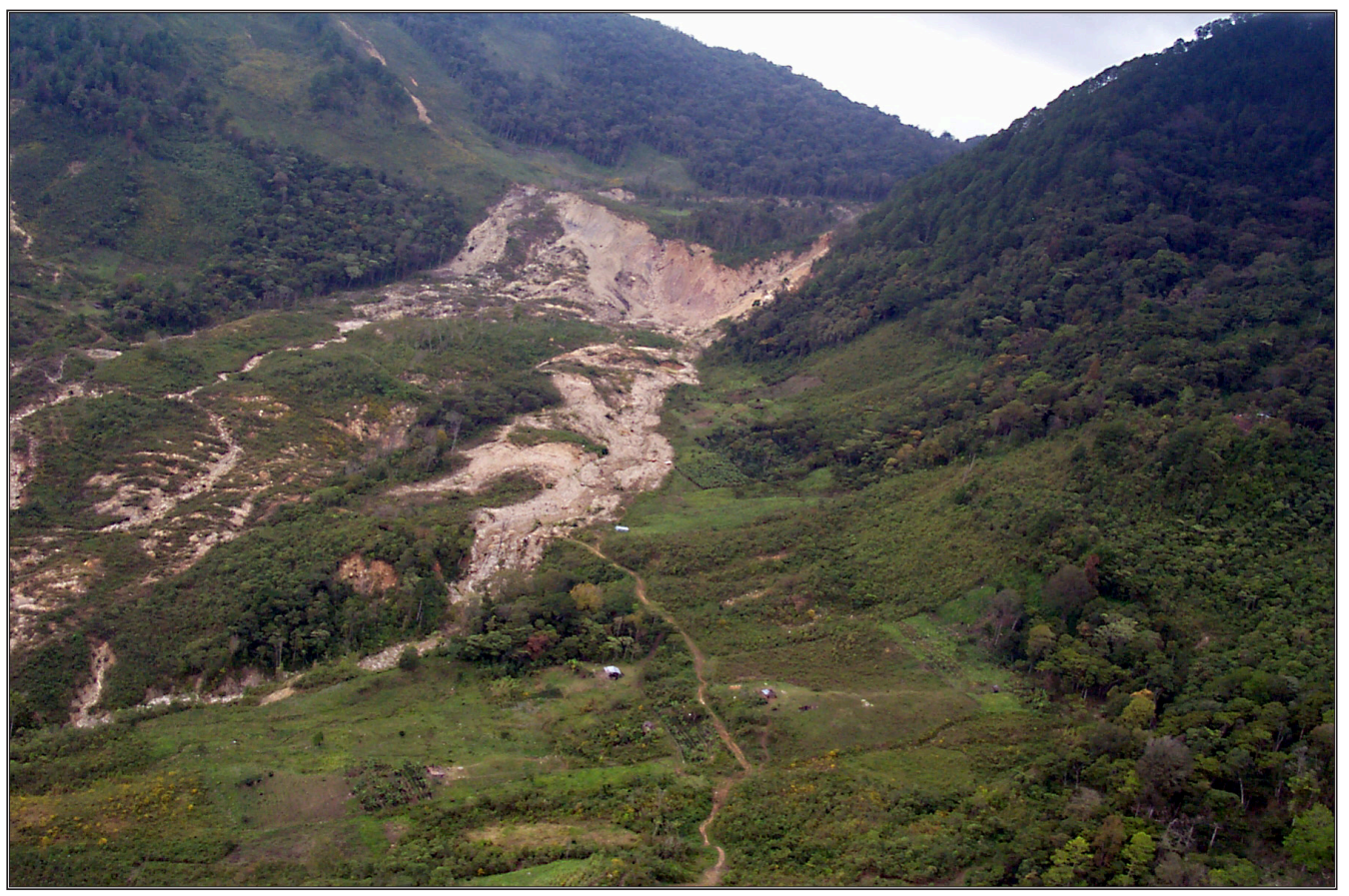

Figure 14. Deep-seated slump/debris flow in the headwaters of Río Chilistagua above El Cajón reservoir.

As can be seen on Plate 6, the upper arm of El Cajón reservoir in the Río Chilistagua drainage is being inundated with sediment. This process will likely continue for many more years during the rainy seasons as high water flows continue to move the sediment downstream into the reservoir. 


\section{La Libertád Quadrangle (2660 II, Plate 7)}

Sediment volume: $2,430,000 \mathrm{~m}^{3}$. Areas of highly concentrated debris flows in the headwaters of the Río Quirima and Río Frío (figure 15) served to destroy many homes that were located in the flood plain of the Río Frío near La Libertád and to send a large stream of sediment down the Río Quirima where it is filling in the arm of El Cajón reservoir where this stream joins the reservoir (figure 10).

The effects of debris flows on people and property were not only felt within the lower parts of river drainages; fatali- ties and destruction of homes occurred in the headwaters of many streams such as the area shown in figure 15 . Here, several homes can be seen close to the margins of many of the debris flow scarps. Although these homes escaped direct impact from debris flows, numerous others did not in this and other mountainous areas throughout Honduras. Debris flows triggered by Hurricane Mitch in similar mountain communities typically destroyed between 5 and 20 homes where debris flows were highly concentrated by heavy rainfall and susceptible geologic units.
Figure 15. Oblique airphoto showing typical debris-flow concentrations in headwaters of Río Frío and Río Quirima.

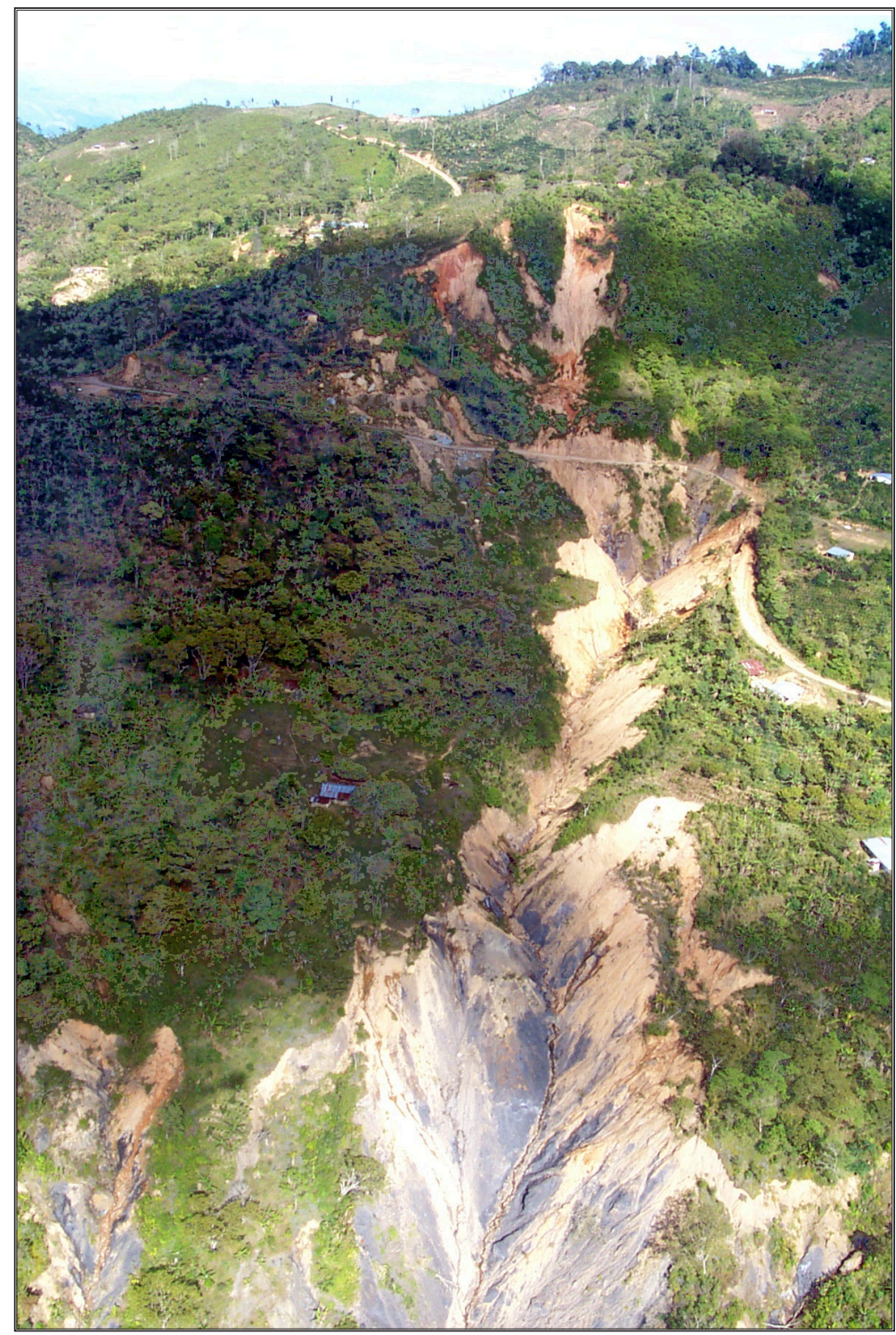


Choluteca Quadrangle (2775 I, Plate 20)

Sediment volume: $1,360,000 \mathrm{~m}^{3}$.

Orocuina Quadrangle (2756 II, Plate 19)

Sediment volume: $1,330,000 \mathrm{~m}^{3}$. Soledad Quadrangle (2756 I, Plate 16)

Sediment volume: $1,450,000 \mathrm{~m}^{3}$. The above three quadrangles lie together in a south to north line in the southern part of the Río Choluteca drainage basin. Although debris flows were highly concentrated in this area, flow paths were not lengthy and the landslide sediment is not well connected to the drainage network of the major streams and rivers. Some of the first- and second-order drainages have debris-flow material within their channels; however, significant transport of this debris into the Río Choluteca will not be likely unless a fairly extreme rainfall event occurs.

\section{Summary}

A $\mathrm{s}$ described by the preceding text and photographs, Honduras and its neighboring countries in Central America suffered an extremely rare climatic event in the form of Hurricane Mitch.

Although Honduras is no stranger to landslides and flooding caused by hurricanes, few events have had the regional extent and severity caused by this hurricane. With over 9,000 fatalities, 3 million people displaced, countrywide flooding, and 500,000 landslides in Honduras alone, Hurricane Mitch has to rank as one of the supreme mass movement events of the century. The initial impact of the flooding and landslides left areas of the country isolated for months. Many of the roads to these areas were finally rebuilt and cleared of landslide debris only to be closed again with the advent of the next rainy season. Even within parts of the country where dense tropical forest cover existed, the scars and travel paths of debris flows inscribed an obvious intense dendritic pattern on
San Lorenzo Quadrangle (2756 III, Plate 18)

Sediment volume: $4,500,000 \mathrm{~m}^{3}$. Debris flows in this quadrangle show high concentrations on the slopes of the low hills which are adjacent to the Gulf of Fonseca and have a relatively short distance to be transported to the Gulf. It is possible that average to slightly above average rainfall seasons may transport a significant fraction of this sediment into the gulf waters and further contribute to the initial pulse of increased sedimentation created by flooding from Hurricane Mitch.

the landscape that is still visible, over three years after the hurricane.

More than 500,000 landslides occurred throughout the country, $95 \%$ of which were debris flows. The debris flows formed flow paths that ranged from a few meters to $7.5 \mathrm{~km}$. Their thicknesses ranged from less than $2 \mathrm{~m}$ which was typical of debris-flow depths in the soils developed in the tropical desert climate near Choluteca to about $15 \mathrm{~m}$ in the cloud forests and tropical forests of other parts of the country. Although few in number, deep-seated landslides had an extremely high impact on people and property in the capitol city of Tegucigalpa and other developed areas (see Harp and others, 2002).

The effects from landslides triggered by Hurricane Mitch will continue to be felt in Honduras for several years to come. Although the initial impact on people and property is over, the continued movement of sediment created by landslides down the watersheds along the 
streams still serves to exacerbate flooding each rainy season and displace residents from their homes. Still, other landslides continue retrogressive movement as their scarps recede upslope involving additional slope area and, in some cases, additional dwellings.

\section{Acknowledgments}

$\mathrm{T}$

he authors would like to acknowledge the assistance of the U.S. Agency for International Development (USAID) and several key individuals whose efforts made the fieldwork, data gathering, and this final report possible. These individuals include: Jeff Phillips of the USGS on temporary duty to USAID as a liaison officer to track all of the USGS effort in Honduras; Adrian Oviedo of USAID who arranged meetings, contacts, and travel for our fieldwork and
Though the landscape will continue to change as erosion and slope instability redistribute landslide sediment and modify existing scarps, the documentation of landslide incidence provided by these landslide inventory plates will hopefully serve to guide future development and land-use decisions in directions that will avoid similar occurrences and subsequent consequences in the coming years.

seminars; and Sherry Thorn, professor of Biology at the University of Honduras who provided translation service, detailed knowledge of all field areas visited in Honduras as well as access to local individuals with eyewitness knowledge of the Hurricane Mitch event, and knowledge of the local customs and practices that proved invaluable for our safety and effectiveness in performing field studies.

We greatly appreciate the graphics and layout design by Eleanor M. Omdahl.

\section{References Cited}

Harp, E. L., Castañeda, M., and Held, M. D., 2002, Landslides triggered by Hurricane Mitch in Tegucigalpa, Honduras, U.S. Geological Survey Open-File Report 02-33, $11 \mathrm{p}, 1$ plate.

Harp, Edwin L., Held, Matthew D., Castañeda, Mario, McKenna, Jonathan, P., and Jibson, Randall W., 2002 (in press), Landslide hazard map of Tegucigalpa, Honduras: U.S. Geological Survey Open-File Report. 